\title{
低衝撃台車のための車輪キャスターの研究*
}

\author{
須田敦 ${ }^{* 1}$, 守屋康治*2, 五百井清*3, 山本昌彦*4
}

\section{Study on a Wheeled Caster for Design of Low-Crash Wagons}

\author{
Atsushi SUDA, Koji MORIYA, Kiyoshi IOI ${ }^{* 3}$ and Masahiko YAMAMOTO
}

${ }^{* 3}$ Kinki University, Faculty of Science and Engineering. 3-4-1, Kowakae, Higashi-osaka, Osaka, 577-8502 Japan

A large number of wheeled casters have been used around the world so that we can push wagons easily. These days, the specifications of casters tend to become severe to keep the wagon vibration lower. Especially, it is very important for patients, medicines and small precision parts to be carried softly and stably. On the other hand, the good design of wheeled casters depends on skills of the engineers who have produced them for years, and the details of the good design are not clarified. In this paper, the mechanics of the wagon caster is discussed to obtain the better design standards. First, we focus on the center of percussion of the wheeled caster to reduce the impulsive force to the wagon. Next, the two-dimensional dynamical model of the wagon is derived to study the reduction effect dependent on the center of percussion. Then, the experimental results are minutely compared to the simulation results using the derived model. From these results, it is clarified that the position of the center of percussion on the caster achieves the reduction of the impulsive force to the wagon when the wagon wheel runs over small bumps. The simulation results based on the dynamical modeling are also verified to have good agreements with experimental results.

Key Words : Center of Percussion, Wheeled Caster, Wagon Dynamics

\section{1. はじめに}

今日，車輪キャスターの取り付けられた台車は，日常の至る所で使用されている．車輪キャスターは，通常の 1 自由度の回転車輪と異なり，路面に垂直方向の旋回軸を有している．その旋回軸の延長線上に車輪接地点がな いことから, 路面上で台車を滑らかに回動させられる特徴がある. 一方, 近年, 医療現場やバイオ・薬品・精密 電子機器の製造現場において，可能な限り路面の影響を受けずに，車台上の患者や搭載物を静かな状態で搬送し たいという要望が強い。このため, キャスター自体を旋回部と摇動アームの 2 つのパーツから構成し，このパー ツ間に粘弾性要素や減衰機構を付加することにより，車台振動を軽減するキャスターが製作されてきた (1)〜(5). このようなキャスターは，車台の振動を素早く減衰させるには大きな効果を発揮する一方で，路面上にある微小 突起等から受ける瞬間的な衝撃力を軽減する効果は少ないと考えられる.

そこで, 本研究では, 車台が路面から受ける衝撃力を軽減することのできるキャスターの機構設計を考察する. キャスターとしては, 車台振動を軽減することを目的とした 2 つパーツからなる機構を前提とする.この場合, キャスターは旋回部と摇動アームからなり, この 2 つのパーツは回転ヒンジにより連結され, その間に粘弾性要 素が介在する構造となる. 通常, 車台の受ける振動や衝撃は上下方向が支配的であると考えられるため, キャス ター旋回部の運動は考慮せず，摇動アームの運動に着目する。この場合，摇動ア一ムの車輪が路面から受ける衝 撃力は，回転ヒンジを介して車台に伝達される.

* 原稿受付 2010 年 12 月 10 日

${ }^{* 1}$ 正員, 近畿大学大学院 (干577-8502 大阪府東大阪市小若江 3-4-1)

*2 近畿大学大学院（干577-8502 大阪府東大阪市小若江 3-4-1)

*3 正員, 近畿大学 理工学部（干577-8502 大阪府東大阪市小若江 3-4-1）

*4 元近畿大学

E-mail: ioi@mech.kindai.ac.jp 
本文では，まず，車台に伝わる力が回転ヒンジを介することと，車輪が路面から受ける衝撃力の作用点がほぼ 車輪の定点であることに着目して, 力学で知られる撃心を利用したキャスター単体の設計を提案する. 次に, 車 台と撃心を考慮したキャスターとを組み合わせた場合の衝撃緩和効果をシミュレーションで確認するために，キ ヤスター付き台車の運動モデルと路面モデルを導出する，続いて，回転ヒンジの取り付け位置が変更できるキャ スターを製作して，キャスター付き台車の突起乗り越え走行実験を行う. 走行実験による車台上下加速度応答と シミュレーションによる車台上下加速度応答から，撃心を考慮したキャスターが車台の衝撃緩和に有効であるこ とを示寸. 最後に, 本研究で得られた成果をまとめ, 今後の課題を述べる.

\section{2. 撃心を考慮した摇動アーム}

摇動アームを有するキャスターと車台からなるキャスター付き台車の側面図を図 1 に示寸．キャスターの旋回 運動は考慮しないため，その旋回軸は省かれているが，図の支柱が旋回部分に相当寸る. なお，台車に複数のキ ヤスターがある場合も同様のため，その描画を省略している．通常，車台振動を低減するために，摇動アームと 支柱の間に適切な粘弾性要素が付加される．また，その要素の弾性効果より，車台と摇動アームの静的釣り合い が保持され，摇動アームはほぼ水平に位置している.

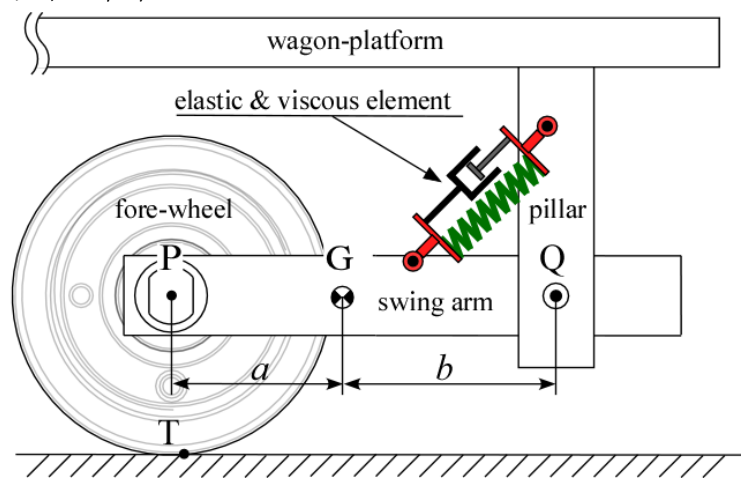

Fig. 1 Side view of wagon with a caster

さて，このキャスター付き台車が路面を等速で走行している場合を想定する．路面が理想的で平坦な場合，台 車には振動も衝撃も伝わらず，車台上下加速度の変動はない，また，路面に微細な凸凹が存在する場合，キャス ターの粘弾性要素や車輪タイヤの粘弾性がこれを吸収するため, 車台加速度はそれほど直接的な影響を受けない. 一方，大きな段差がある場合，台車操作者の目視が可能なため，操作者が何らかの判断を行い，台車をそのまま 段差に衝突させることはない，最も深刻な問題は，路面に数ミリ程度の突起等がある場合，目視が難しく，台車 が等速で乗り越えてしまい，思わぬ大きな衝撃が車台に伝わることである．この問題を解決する方法として，摇 動アームの撃心に着目した設計を提案する.

力学における撃心は, 静止している平面剛体のある点に瞬間的な力が作用するとき, 剛体の重心 $\mathrm{G}$ と力の作用 点 $\mathrm{P}$ の位置関係, およびその質量 $M$ と重心まわりの慣性モーメント $I_{G}$ から決定される点 $\mathrm{Q}$ として定義される ${ }^{(6)}$, (7). このとき, 撃心 $\mathrm{Q}$ では瞬間的に静止した状態となる. 図 1 を例にとると, 車輪中心 $\mathrm{P}$ に鉛直方向の衝撃力が 加わった場合, PG 間の距離を $a$ と寸ると, 撃心を特徵づける GQ 間の距離 $b$ は以下の関係式により一意に決定さ れる.

$$
M a b=I_{G} .
$$

古くから，撃心を考慮した機器として，野球のバット，ゴルフクラブ，テニスラケット等が知られている ${ }^{(8)}$ (10). また, 近年, ロボットの打撃作業や運動計画に応用した例も見られるが ${ }^{(11)} \sim(13)$, キャスターに適用した例 は見当たらない.

撃心の衝撃低減効果は, 衝撃力の作用点が不変であることと衝撃力の方向が重心と撃心を結ぶ直線に直交して いることに依存している．図1におけるキャスターの摇動アームが受ける衝撃力は，現実には路面の突起と車輪 の接触点 $\mathrm{T}$ にて生じる. 先に述べたように, 対象とする突起は数ミリ程度であるため, ある程度の車輪径を有す 
るキャスターの場合，その車輪の接触点 $\mathrm{T}$ は車輪中心 $\mathrm{P}$ のほぼ鉛直下にあると見なせる．さらに，車輪が接触点 $\mathrm{T}$ を介して突起から受ける衝撃力は，前方から受ける分力に比べて鉛直上方向の分力が大きく，この鉛直上方向 の分力が車輪中心 $\mathrm{P}$ に伝わり，点 $\mathrm{Q}$ に最も大きな影響を与えると予想される.

そこで，図 1 の摇動アームに関して式（1）の関係を満足するような設計を行い，撃心 Q が支柱の回転ヒンジ 中心と一致するよう組み付けることで，車台に伝わる衝撃力を低減することを試みる.

以上の提案と推察では, 摇動アームと支柱の間に存在する粘弹性要素の影響や車輪の有する夕イヤ粘弾性部の 影響等が考慮されていない，これらの影響を簡単に見積もることは難しいため，次章以降にてキャスター付き台 車の詳細モデリングを行う。また，ヒンジ中心を変更できる摇動アームを試作し，これを使用した台車走行の実 験結果により撃心の効果を論じる．また，同時にシミュレーション結果との比較検討を行う．

\section{3. キャスター付き台車と路面のモデリング}

\section{$3 \cdot 1$ キャスター付き台車の基本運動モデル}

キャスター付き台車は, 車台および摇動アームを有するキャスターからなる 2 次元平面モデルとして取り扱う. 前輪は摇動アーム端に取り付けられ, 後輪は支柱の直下に取り付けられている. 前輪, 後輪ともタイヤ粘弾性を 有するとする.さらに，支柱と摇動アーム間に粘弾性要素が付加されている．対象とする本モデルの側面図を図 2 に示寸. ここで, 点 $\mathrm{P}$ は前輪中心, 点 $\mathrm{Q}$ は支柱と摇動アームを連結するヒンジ中心, 点 $\mathrm{R}$ は後輪中心を表す. 点 $\mathrm{T}_{1}$ と点 $\mathrm{T}_{2}$ は, 前輪および後輪の路面との接触点である. また, 点 $\mathrm{G}_{1}$ と点 $\mathrm{G}_{2}$ は, それぞれ摇動アームの重心 と車台の重心（支柱部を含む）を表す。さらに, 粘弾性要素の取り付け両端点 A, B は, 点 A が摇動アーム側に あり，点 Bが支柱（車台）側にあるとする.

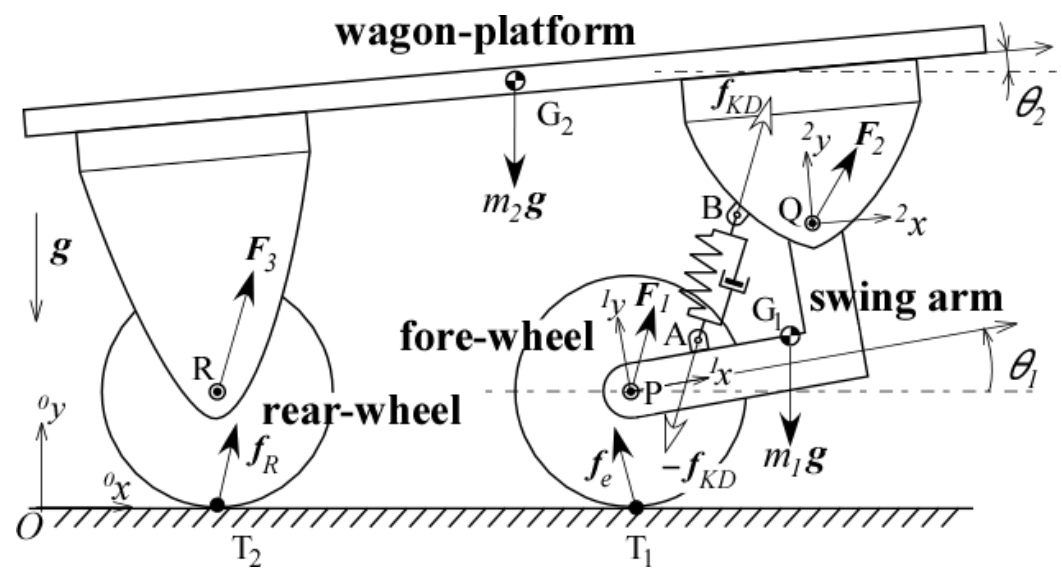

Fig.2 Two-dimensional wagon model with a caster

運動方程式を導出するにあたり, 車台の質量と慣性モーメント, 摇動アームの質量と慣性モーメントを考慮し, 前後輪は質量だけを考慮する．ただし，前輪の慣性モーメントは摇動アームの慣性モーメントに含める．路面を 慣性座標系に設定し, 前輪中心 $\mathrm{P}$ の位置ベクトルを $\boldsymbol{x}_{P}$, 摇動アーム重心 $\mathrm{G}_{1}$ の位置ベクトルを $\boldsymbol{x}_{1}$, 車台重心 $\mathrm{G}_{2}$ の位置ベクトルを $\boldsymbol{x}_{2}$, 後輪中心 $\mathrm{R}$ の位置ベクトルを $\boldsymbol{x}_{R}$, 摇動アームの路面からの回転角を $\theta_{1}$, 車台の路面から の回転角を $\theta_{2}$ とする. このとき，車台と摇動アームに Newton-Euler の運動方程式を適用し，前後輪に Newton の 運動方程式を適用した後, 内部拘束力を消去すると, 以下の 4 つのスカラー方程式を得る.

$$
\begin{gathered}
m_{p}\left(\ddot{\boldsymbol{x}}_{p}+\boldsymbol{g}\right)+m_{1}\left(\ddot{\boldsymbol{x}}_{1}+\boldsymbol{g}\right)+m_{2}\left(\ddot{\boldsymbol{x}}_{2}+\boldsymbol{g}\right)+m_{R}\left(\ddot{\boldsymbol{x}}_{R}+\boldsymbol{g}\right)=\boldsymbol{f}_{e}+\boldsymbol{f}_{R}, \\
I_{1} \ddot{\theta}_{1}+m_{1} \boldsymbol{g}_{1} \otimes\left(\ddot{\boldsymbol{x}}_{1}+\boldsymbol{g}\right)+m_{2} \boldsymbol{l} \otimes\left(\ddot{\boldsymbol{x}}_{2}+\boldsymbol{g}\right)+m_{R} \boldsymbol{l} \otimes\left(\ddot{\boldsymbol{x}}_{R}+\boldsymbol{g}\right)=(\boldsymbol{l}-\boldsymbol{a}) \otimes \boldsymbol{f}_{K D}+\boldsymbol{l} \otimes \boldsymbol{f}_{R}, \\
I_{2} \ddot{\theta}_{2}+m_{2} \boldsymbol{g}_{2} \otimes\left(\ddot{\boldsymbol{x}}_{2}+\boldsymbol{g}\right)+m_{R} \boldsymbol{L} \otimes\left(\ddot{\boldsymbol{x}}_{R}+\boldsymbol{g}\right)=\boldsymbol{b} \otimes \boldsymbol{f}_{K D}+\boldsymbol{L} \otimes \boldsymbol{f}_{R} .
\end{gathered}
$$


ここで, 演算記号 $\otimes は ， 2$ 次元ベクトルのベクトル積を表し, 結果はスカラー值をとるものとする. 以下に, 上式で使用した諸記号の意味を記述する，ただし，ベクトルの左上添え字 $0,1 ， 2$ は，それぞれ，路面座標系表 現，摇動アーム座標系表現，車台座標系表現を表している.

$m_{p}, m_{R}, m_{1}, m_{2}$ : 前輪の質量, 後輪の質量, 摇動アームの質量, 車台の質量.

$I_{1}, I_{2}$ : 重心 $\mathrm{G}_{1}$ まわりの摇動アームの慣性モーメント, 重心 $\mathrm{G}_{2}$ まわりの車台の慣性モーメント.

${ }^{0} \boldsymbol{g}=\left(\begin{array}{ll}0 & g\end{array}\right)^{T}:$ 重力加速度ベクトル,

${ }^{1} \boldsymbol{l}=\left(\begin{array}{ll}l_{x} & l_{y}\end{array}\right)^{T}:$ 点 $\mathrm{P}$ から点 $\mathrm{Q} へ の$ 位置ベクトル,

${ }^{1} \boldsymbol{a}=\left(\begin{array}{ll}a_{x} & a_{y}\end{array}\right)^{T}:$ 点 $\mathrm{P}$ から点 $\mathrm{A}$ への位置ベクトル,

${ }^{2} \boldsymbol{b}=\left(\begin{array}{ll}b_{x} & b_{y}\end{array}\right)^{T}:$ 点 $\mathrm{Q}$ から点 $\mathrm{B}$ への位置ベクトル,

${ }^{1} g_{1}=\left(\begin{array}{ll}g_{1 x} & g_{1 y}\end{array}\right)^{T}:$ 点 $\mathrm{P}$ から点 $\mathrm{G}_{1}$ への位置ベクトル,

${ }^{2} \boldsymbol{g}_{2}=\left(\begin{array}{ll}g_{2 x} & g_{2 y}\end{array}\right)^{T}:$ 点 $\mathrm{Q}$ から点 $\mathrm{G}_{2}$ への位置ベクトル,

${ }^{2} \boldsymbol{L}=\left(\begin{array}{ll}L_{x} & L_{y}\end{array}\right)^{T}:$ 点 $\mathrm{Q}$ から点 $\mathrm{R}$ への位置ベクトル,

$f_{e}:$ 前輪接触点 $\mathrm{T}_{1}$ が路面より受ける外力,

$f_{R}:$ 後輪接触点 $\mathrm{T}_{2}$ が路面より受ける外力,

$f_{K D}$ : 点 $\mathrm{A}$ から点 $\mathrm{B}$ に向かう粘弾性要素の力.

式（2）～（4）には，位置ベクトル $\boldsymbol{x}_{1}, \boldsymbol{x}_{2}, \boldsymbol{x}_{R}$ に関する時間微分項が含まれるが，これらの位置ベクトルは $\boldsymbol{x}_{P}, \theta_{1}, \theta_{2}$ を使って表現できる. このため, 式 (2) 〜 (4) は $\boldsymbol{x}_{P}=\left(x_{P}, y_{P}\right)^{T}, \theta_{1}, \theta_{2}$ の 4 変数からなる時間 に関する 2 階連立微分方程式となる. ここで, 台車の路面走行方向 ( ${ }^{0} x$ 方向) の運動が車台の上下運動に与える 影響は少ないと判断し, 台車の走行方向の運動は路面自体を移動させることにより代用する. これにより, 式 (2) 〜 (4) は $y_{P}, \theta_{1}, \theta_{2}$ の 3 変数だけの運動方程式とすることができる. この方針で式 (2) 〜 (4) を整理する ことにより，最終的に以下の運動方程式表現を得る.

$$
H(\boldsymbol{q}) \ddot{\boldsymbol{q}}+\boldsymbol{h}(\boldsymbol{q}, \dot{\boldsymbol{q}})+\boldsymbol{G}(\boldsymbol{q})=\boldsymbol{F}(\boldsymbol{q}, \dot{\boldsymbol{q}}) .
$$

この具体的な行列とベクトルの成分は以下である.

$$
\begin{aligned}
& \boldsymbol{q}=\left(\begin{array}{lll}
y_{P} & \theta_{1} & \theta_{2}
\end{array}\right)^{T}, \quad M \equiv m_{p}+m_{1}+m_{2}+m_{R}, \\
& H(\boldsymbol{q}) \equiv\left(\begin{array}{ccc}
M & m_{1}\left(C_{1} g_{1 x}-S_{1} g_{1 y}\right) & -m_{2}\left(-C_{2} g_{2 x}+S_{2} g_{2 y}\right) \\
& +\left(m_{2}+m_{R}\right)\left(C_{1} l_{x}-S_{1} l_{y}\right) & -m_{R}\left(-C_{2} L_{x}+S_{2} L_{y}\right) \\
* & I_{1}+m_{1}\left(g_{1 x}^{2}+g_{1 y}^{2}\right) & \left(m_{2} g_{2 x}+m_{R} L_{x}\right)\left(C_{1-2} l_{x}-S_{1-2} l_{y}\right) \\
& +\left(m_{2}+m_{R}\right)\left(l_{x}^{2}+l_{y}^{2}\right) & +\left(m_{2} g_{2 y}+m_{R} L_{y}\right)\left(S_{1-2} l_{x}+C_{1-2} l_{y}\right) \\
\text { (sym. }) & * & I_{2}+m_{2}\left(g_{2 x}^{2}+g_{2 y}^{2}\right)+m_{R}\left(L_{x}^{2}+L_{y}^{2}\right)
\end{array}\right), \\
& \boldsymbol{h}(\boldsymbol{q}, \dot{\boldsymbol{q}}) \equiv\left(\begin{array}{c}
-\left\{m_{1}\left(S_{1} g_{1 x}+C_{1} g_{1 y}\right)+\left(m_{2}+m_{R}\right)\left(S_{1} l_{x}+C_{1} l_{y}\right)\right\}\left(\dot{\theta}_{1}\right)^{2} \\
-\left\{m_{2}\left(S_{2} g_{2 x}+C_{2} g_{2 y}\right)+m_{R}\left(S_{2} L_{x}+C_{2} L_{y}\right)\right\}\left(\dot{\theta}_{2}\right)^{2} \\
\left\{\left(m_{2} g_{2 x}+m_{R} L_{x}\right)\left(S_{1-2} l_{x}+C_{1-2} l_{y}\right)-\left(m_{2} g_{2 y}+m_{R} L_{y}\right)\left(C_{1-2} l_{x}-S_{1-2} l_{y}\right)\right\}\left(\dot{\theta}_{2}\right)^{2} \\
\left\{-\left(m_{2} g_{2 x}+m_{R} L_{x}\right)\left(S_{1-2} l_{x}+C_{1-2} l_{y}\right)+\left(m_{2} g_{2 y}+m_{R} L_{y}\right)\left(C_{1-2} l_{x}-S_{1-2} l_{y}\right)\right\}\left(\dot{\theta}_{1}\right)^{2}
\end{array}\right),
\end{aligned}
$$




$$
\begin{gathered}
\boldsymbol{G}(\boldsymbol{q}) \equiv\left(\begin{array}{c}
M g \\
\left\{m_{1}\left(C_{1} g_{1 x}-S_{1} g_{1 y}\right)+\left(m_{2}+m_{R}\right)\left(C_{1} l_{x}-S_{1} l_{y}\right)\right\} g \\
\left\{m_{2}\left(C_{2} g_{2 x}-S_{2} g_{2 y}\right)+m_{R}\left(C_{2} L_{x}-S_{2} L_{y}\right)\right\} g
\end{array}\right), \\
\boldsymbol{F}(\boldsymbol{q}, \dot{\boldsymbol{q}}) \equiv\left(\begin{array}{c}
{ }^{0} f_{e y}+{ }^{0} f_{R y} \\
{ }^{1}(\boldsymbol{l}-\boldsymbol{a}) \otimes{ }^{1} \boldsymbol{f}_{K D}+{ }^{0} \boldsymbol{l} \otimes{ }^{0} \boldsymbol{f}_{R} \\
{ }^{1} \boldsymbol{b} \otimes{ }^{1} \boldsymbol{f}_{K D}+{ }^{0} \boldsymbol{L} \otimes{ }^{0} \boldsymbol{f}_{R}
\end{array}\right) .
\end{gathered}
$$

ただし，上記行列の成分表現にて，

$S_{1}=\sin \theta_{1}, C_{1}=\cos \theta_{1}, S_{2}=\sin \theta_{2}, C_{2}=\cos \theta_{2}, S_{1-2}=\sin \left(\theta_{1}-\theta_{2}\right), C_{1-2}=\cos \left(\theta_{1}-\theta_{2}\right)$ と略記した.

式（5）における作用力項 $\boldsymbol{F}(\boldsymbol{q}, \dot{\boldsymbol{q}})$ は，粘弾性要素の発生する力と車輪が路面から受ける力から構成される.こ れらの力の記述について次節に示す.

\section{$3 \cdot 2$ 粘弾性要素力と車輪外力のモデル}

まず，粘弾性要素が発生する受動力 $\boldsymbol{f}_{K D}$ を記述する．受動力は，取り付け点 $\mathrm{A} ， \mathrm{~B}$ の位置および速度により表 現されるから，ばね・ダンパを想定した線形粘弾性特性を仮定すると， $\boldsymbol{f}_{K D}$ は次式により与えられる.

$$
{ }^{1} \boldsymbol{f}_{K D}=\left(K(l-\|\overrightarrow{A B}\|)-D \frac{d}{d t}\|\overrightarrow{A B}\|\right) \frac{1 \overrightarrow{A B}}{\|\overrightarrow{A B}\|} .
$$

ここで， $K$ および $D$ は，線形粘弾性特性のばね定数と粘性係数であり，l は基準となるばね自然長を表す。こ の例の場合，具体的な計算を行うと，以下の表現を得る.

$$
{ }^{1} \boldsymbol{f}_{K D}=\left\{K\left(l-\sqrt{d_{x}^{2}+d_{y}^{2}}\right)-\frac{D\left(-d_{x} h_{y}+d_{y} h_{x}\right)\left(\dot{\theta}_{1}-\dot{\theta}_{2}\right)}{\sqrt{d_{x}^{2}+d_{y}^{2}}}\right\} \frac{1}{\sqrt{d_{x}^{2}+d_{y}^{2}}}\left(\begin{array}{c}
d_{x} \\
d_{y}
\end{array}\right) .
$$

ただし $h_{x}=l_{x}-a_{x}, h_{y}=l_{y}-a_{y}, d_{x}=h_{x}+C_{1-2} b_{x}+S_{1-2} b_{y}, d_{y}=h_{y}-S_{1-2} b_{x}+C_{1-2} b_{y} \quad$ である.

次に, 前後輪が路面より受ける力 $\boldsymbol{f}_{e}$ と $\boldsymbol{f}_{R}$ について述べる. 前後輪とも線形粘弾性を有するタイヤ車輪を 仮定する. なお，進行方向の車輪転がり抵抗力は小さいとして， $f_{e x}=f_{R x}=0$ とする.

前輪が平坦な路面にて走行する場合 (図 3 を参照)，それが受ける鋁直方向の外力を以下で記述する.

$$
f_{e y}=K_{T}\left(R-y_{P}\right)-C_{T} \dot{y}_{P} .
$$

ここで, $K_{T}$ および $C_{T}$ は, 前輪タイヤのばね定数と粘性係数を示し, $R$ はタイヤの自然半径を示す.

一方, 前輪が走行時に硬い路面突起に衝突する場合, それが受ける鉛直方向の外力を以下で記述する.

$$
f_{e y}=\left(K_{T} \Delta Z+C_{T} \Delta \dot{Z}\right) \frac{y_{P}}{\sqrt{\left(a-x_{P}\right)^{2}+y_{P}^{2}}} .
$$

ここで， $\Delta Z$ および $\Delta \dot{Z}$ は，車輪と突起物との図形的重なり長さとその速度を表し，突起物は半円形形状を想 定している (図 4 を参照)。この場合， $\Delta Z$ および $\Delta \dot{Z}$ は以下で表現され， $a$ および $r$ は，半円突起の中心位置と 半径を表している.

$$
\Delta Z=(R+r)-\sqrt{\left(a-x_{P}\right)^{2}+y_{P}^{2}}, \quad \Delta \dot{Z}=\frac{1}{\sqrt{\left(a-x_{P}\right)^{2}+y_{P}^{2}}}\left\{\left(a-x_{P}\right) \dot{x}_{P}-y_{P} \dot{y}_{P}\right\} .
$$




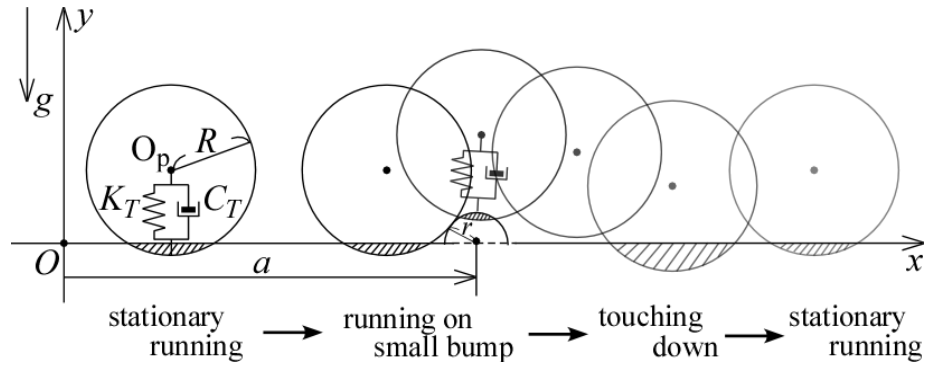

Fig. 3 Motion appearance of one wheel

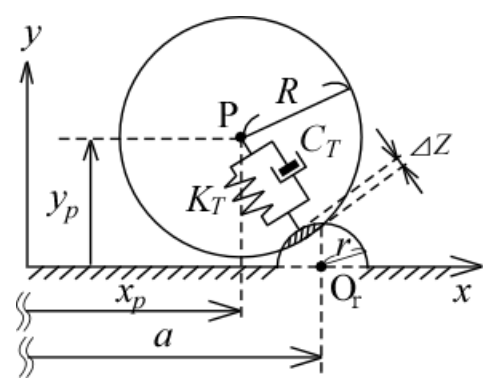

Fig. 4 Contact with a semicircular bump

最後に，後輪が路面より受ける鋁直方向の外力について述べる．後輪中心 $\mathrm{R} の y$ 座標に関しては，以下の図形 的関係式が成立する.

$$
y_{R}=y_{p}+S_{1} l_{x}+C_{1} l_{y}+S_{2} L_{x}+C_{2} L_{y}, \dot{y}_{R}=\dot{y}_{p}+\left(C_{1} l_{x}-S_{1} l_{y}\right) \dot{\theta}_{1}+\left(C_{2} L_{x}-S_{2} L_{y}\right) \dot{\theta}_{2} .
$$

したがって, 前輪の位置, 速度, および摇動アームと車台の角度, 角速度から, 後輪中心の位置と速度が得ら れる. 式（11）を利用して，以下の式より，後輪の鉛直方向の外力が求められる.

$$
f_{R y}=K_{T}\left(R-y_{R}\right)-C_{T} \dot{y}_{R}
$$

なお, 式（8）と式（9）の状態判別は, 前輪中心位置 $\boldsymbol{x}_{P}=\left(x_{P}, y_{P}\right)^{T}$ から得られる $\Delta Z$ の正負により行い, 台 車の走行方向運動は前輪中心 $\mathrm{P}$ の走行速度 $\dot{x}_{P}$ を変化させることにより模擬する.

\section{4. キャスター付き台車の衝撃応答実験}

\section{$4 \cdot 1$ 実験用摇動アームの設計}

2 章で述べた撃心を考慮した摇動アームの衝撃緩和効果を確認するために，実験用摇動アームを製作した．そ の側面図を図 5 に示寸．支柱の回転ヒンジ中心と連結するために，摇動アームに 7 つ連結ホールを設けた．図 中にて, 最も左端のホール中心が $\mathrm{Q}_{1}$, 真ん中のホール中心が $\mathrm{Q}_{2}$, 最も右端のホール中心が $\mathrm{Q}_{3}$ である. 支柱の回 転ヒンジ中心と連結する摇動アームのホールを取り換えた実験を行うことにより, 連結ホール位置が車台に与え る衝撃の影響を比較することができる．製作した実験用摇動アームとそれに付随するタイヤ部の特徴的寸法と力 学特性を表 1 に示す. なお, 本摇動アームの場合, ホール中心 $\mathrm{Q}_{2}$ が設計上の撃心に対応している.

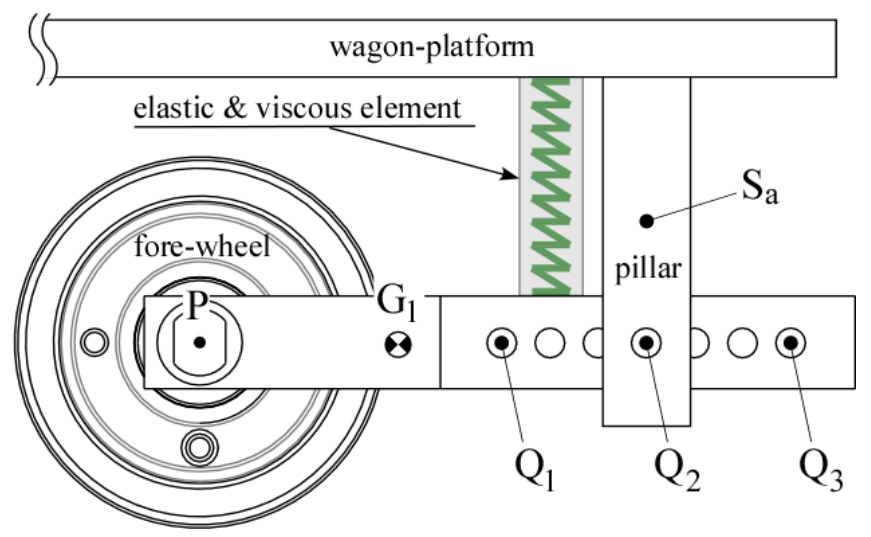

Table 1 Parameters of swing arm

\begin{tabular}{|c|c|c|c|c|}
\hline & Symbol & value & Symbol & value \\
\hline \hline \multirow{2}{*}{$Q_{1}$} & $a_{x}[\mathrm{~mm}]$ & 62.5 & $a_{y}[\mathrm{~m}]$ & 12.5 \\
\cline { 2 - 5 } & $l_{x}[\mathrm{~mm}]$ & 88.5 & $l_{y}[\mathrm{~m}]$ & 0 \\
\hline \multirow{2}{*}{$Q_{2}$} & $a_{x}[\mathrm{~mm}]$ & 101.5 & $a_{y}[\mathrm{~m}]$ & 12.5 \\
\cline { 2 - 5 } & $l_{x}[\mathrm{~mm}]$ & 127.5 & $l_{y}[\mathrm{~m}]$ & 0 \\
\hline \multirow{2}{*}{$Q_{3}$} & $a_{x}[\mathrm{~mm}]$ & 140.5 & $a_{y}[\mathrm{~m}]$ & 12.5 \\
\cline { 2 - 5 } & $l_{x}[\mathrm{~mm}]$ & 166.5 & $l_{y}[\mathrm{~m}]$ & 0 \\
\hline \multicolumn{2}{|c|}{$g_{l x}[\mathrm{~mm}]$} & 55.2 & $g_{l y}[\mathrm{~mm}]$ & 0 \\
\hline \multicolumn{2}{|c|}{$m_{1}[\mathrm{~kg}]$} & 0.4675 & $I_{l}\left[\mathrm{~kg} \cdot \mathrm{mm}^{2}\right]$ & $1.5 \times 10^{3}$ \\
\hline \multicolumn{2}{|c|}{$m_{p}, m_{r}[\mathrm{~kg}]$} & 0.3742 & $R_{l}, R_{2}[\mathrm{~mm}]$ & 50 \\
\hline \multicolumn{2}{|c|}{$K_{T}[\mathrm{~N} / \mathrm{mm}]$} & 400 & $C_{T}[\mathrm{~N} \cdot \mathrm{s} / \mathrm{mm}]$ & 0.4 \\
\hline
\end{tabular}

Fig. 5 Side view of experimental swing arm 


\section{$4 \cdot 2$ 台車の突起乗り越え実験}

実験に使用するキャスター付き台車の全体像を図 6 に示す。支柱と摇動アーム間に取り付ける粘弾性要素は交 換可能となっている．粘弾性要素は，車台の負荷に応じて摇動アームがほぼ水平に釣り合う部品を選択する．負 荷を搭載しない車台の特徵パラメータを表 2 に示す.

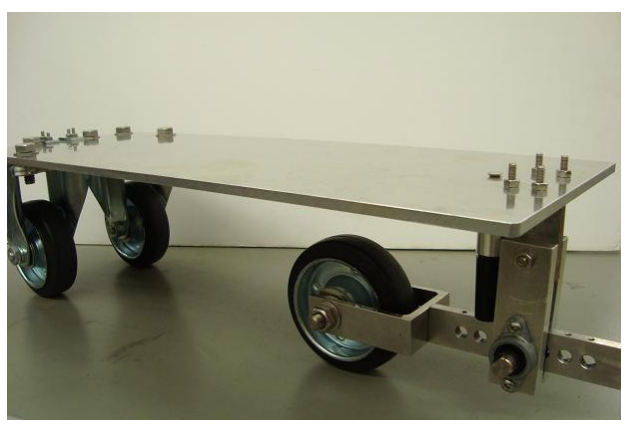

Table 2 Parameters of wagon platform

Fig. 6 Overview of experimental wagon

実験用路面はアルミ板とし, その上に半径 $2.5 \mathrm{~mm}$ の円筒状突起を設ける. キャスター付き台車を等速走行させ, 突起に乗り上げる直前直後の車台に及ぼす衝撃を観察する。台車の等速走行のために，市販の電動単軸アクチュ エータ（ミスミ製，型番 RS-3）を利用する。この単軸アクチュエータの先端部を台車後部と連結し，アクチュエ 一タが台車を等速に押し出すことにより，台車の等速運動を実現する．なお，車台の衝撃力を直接計測すること が難しいので，図 5 の点 $\mathrm{S}_{\mathrm{a}}$ に加速度センサを取り付け，その上下加速度を計測することで代用する．なお，突起 に衝突させる台車の速度は，60 mm/s とした。この速度は，単軸アクチュエータを速度制御することにより達成 される.

本実験では，粘弾性要素として単体のコイルばねとコイルばねを埋没させたウレタンダンパを使用する。本ウ レタンダンパは，車台の振動を素早く減衰させるために開発された製品である。 ${ }^{(14)}$ 使用したコイルばねとばね 埋没型ウレタンダンパの特徵パラメータを表 3 - a), b)に示す。なお，ウレタンダンパのばね定数は，単体のコイ ルばねのばね定数と近いものを選択した。

Table 3 Parameters of elastic and viscous elements

\begin{tabular}{|c|c|}
\hline symbol & value \\
\hline \hline$l[\mathrm{~mm}]$ & 40 \\
\hline$K[\mathrm{~N} / \mathrm{mm}]$ & 64.6 \\
\hline$D[\mathrm{Ns} / \mathrm{mm}]$ & 0.023 \\
\hline
\end{tabular}

a) Coiled spring

\begin{tabular}{|c|c|}
\hline symbol & value \\
\hline \hline$l[\mathrm{~mm}]$ & 40 \\
\hline$K[\mathrm{~N} / \mathrm{mm}]$ & 66.7 \\
\hline$D[\mathrm{Ns} / \mathrm{mm}]$ & 0.288 \\
\hline
\end{tabular}

b) Urethane damper

表 3 - a)のコイルばねを取り付けて実験を行った結果を図 7 に示す. 支柱の回転ヒンジ中心と連結する摇動ア一 ムのホールを $\mathrm{Q}_{1}, \mathrm{Q}_{2}, \mathrm{Q}_{3}$ に取り換えた場合の支柱点 $\mathrm{S}_{\mathrm{a}}$ における上下加速度応答を示す. 図の矢印で示した個所に て車輪と突起との衝突が生じ，大きな衝撃加速度が発生している。ここで，時間軸に沿って最初に現れる第 1 衝 撃加速度が前輪と突起との衝突による影響である. 衝突直後に, 点 $\mathrm{Q}_{1}$ では加速度が正方向に生じているのに対し, 点 $\mathrm{Q}_{3}$ では負方向に生じており，支柱の回転ヒンジ中心に対する衝撃方向が変化していることが見てとれる. 点 $\mathrm{Q}_{2}$ は設計上の撃心であることから理想的には衝突直後に零加速度となるはずであるが, 負方向の加速度が生じて いる．この原因は，摇動アームの設計值と実物では撃心位置に多少のずれがあること，回転ヒンジに大きさがあ るため作用・反作用点が必ずしもヒンジ中心にないこと, 取り付け時の摇動アームが完全に水平でないこと等が 考えられる. しかしながら, 回転ヒンジ中心が点 $\mathrm{Q}_{2}$ である場合の第 1 衝撃加速度の大きさは, 回転ヒンジ中心が 点 $\mathrm{Q}_{1}$ の場合のそれに比較して減少しており，衝撃緩和効果が見てとれる. また，回転ヒンジ中心が点 $\mathrm{Q}_{2}$ である 場合，続いて現れる正方向の加速度はやや大きくなる傾向があるが，その後の 0.1 秒間程度の突起への接触衝突 現象に着目すると, 負方向の加速度の大きさが半減していることがわかる. 回転ヒンジ中心が点 $\mathrm{Q}_{2}$ の場合と点 $\mathrm{Q}_{3}$ の場合とを比較すると, 最初に突起に衝突した時点での衝撃加速度の大きさは点 $\mathrm{Q}_{2}$ のほうが小さく, その後 の加速度の大きさも, 撃心対応点 $\mathrm{Q}_{2}$ のほうが減少していると判断される. 
次に, 表 3-b)のウレタンダンパを取り付けて実験を行った結果を図 8 に示す. 先にも述べたように, 本ウレタ ンダンパは車台の減衰効果を高めるために開発されたため，コイルばねの実験結果である図 7 と比較すると突起 乗り越え後の加速度の減衰に優れている. 一方で, 表 3 に示したように, ウレタンダンパのばね定数は単体のコ イルばねのばね定数とほとんど等しいため，突起衝突前後の加速度の過渡応答に関してはほとんど差異が見られ ない. すなわち, 衝撃応答はダンピング係数にはほとんじ影響されず, ばね定数に依存すると推測される. なお, 摇動アームのホールを $\mathrm{Q}_{1}, \mathrm{Q}_{2}, \mathrm{Q}_{3}$ に取り換えた衝撃加速度の結果は，本ウレタンダンパの場合も単体のコイルばね を取り付けた場合と同様に, 撃心対応点 $\mathrm{Q}_{2}$ が回転ヒンジ中心にある場合が最も衝撃加速度を抑えられることを示 している.

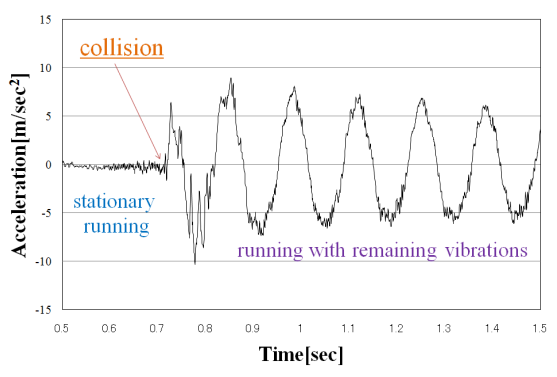

a) Hinge center $Q_{1}$

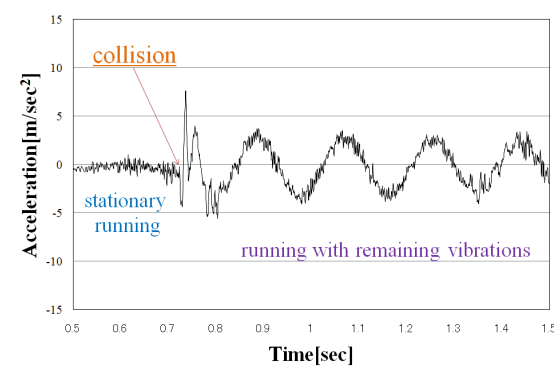

b) Hinge center $Q_{2}$

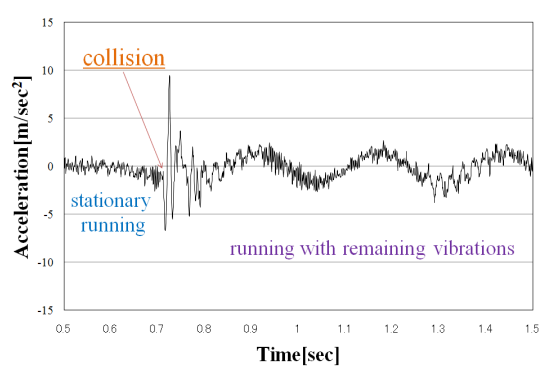

c) Hinge center $Q_{3}$

Fig.7 Experimental results of wagon with a coiled spring

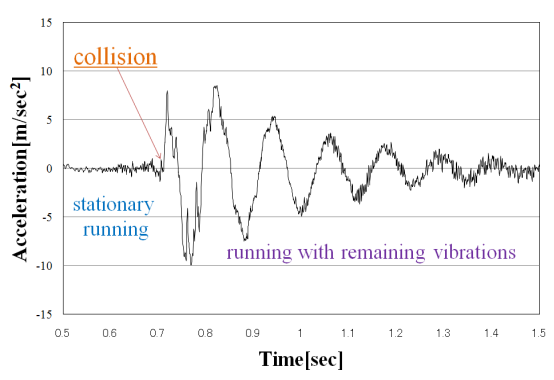

a) Hinge center $Q_{1}$

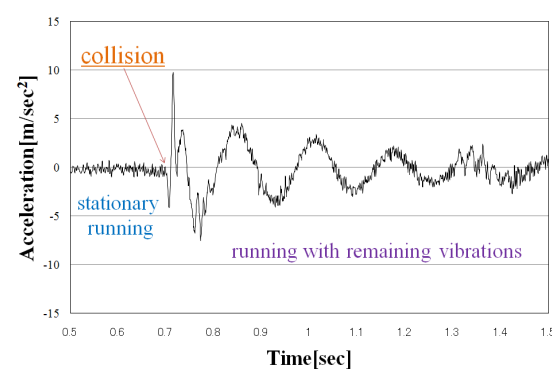

b) Hinge center $Q_{2}$

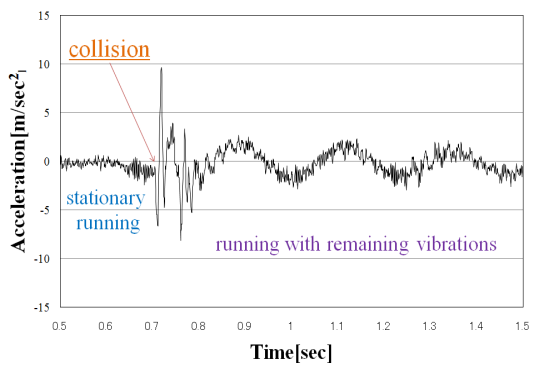

c) Hinge center $Q_{3}$

Fig.8 Experimental results of wagon with a urethane damper

\section{$4 \cdot 3$ 台車の突起乗り越えシミュレーション}

3 章にて導出した台車の力学モデルをベースに, Matlab/Simulink を利用してシミュレータを作成した. シミュ レーションに使用したパラメータは, 設計段階で得られている表 1 , 表 2 , 表 3 である. 粘弾性要素として, 単体 のコイルばねを使用した場合のシミュレーション結果を図 9 に，ウレタンダンパを使用した場合の結果を図 10 に示す. 実験結果の図 7 とシミュレーション結果の図 9 を比較すると, 突起衝突前後の衝撃加速度の振る舞いと 大きさが似通っていることが分かる．また，前輪が突起を乗り越え路面に着地した直後に台車の固有振動数を伴 って摇れ始める位相がほぼ一致しており, 着地後に残る残留振動の固有振動数も近い值となっている. ただし, 回転ヒンジ中心が点 $\mathrm{Q}_{2}$ と点 $\mathrm{Q}_{3}$ の場合, シミュレーション結果では実験結果と比較して, 第 1 衝撃加速度の後に 生じる正方向の加速度が小さくなる傾向がある．この大きさの相違は，実験台車に使用しているキャスター前輪 および後輪の車軸穴と車軸の隙間が影響しているものと予想される. 今回の実験では，前後輪に市販の台車車輪 を使用したが，この隙間は手で動かしても感じられる程度にある.この影響は前輪の突起衝突前後のみならず， 突起乗り越え後の残留振動にも重盢していることが, 回転ヒンジ中心が点 $\mathrm{Q}_{3}$ の場合のシミュレーション結果 (図 9-c））と実験結果（図 7-c））とを比較することにより確認される，以上は，実験結果とシミュレーション結 果の相違点に関する推測であるが, 詳細の解決は今後の課題である. なお, 実験結果の図 8 とシミュレーション 結果の図 10 を比較しても, 同様のよい一致が見られるため, 本研究にて作成した力学モデルはキャスター付台車 の突起乗り越え運動をよく表現していると考えられる. 最後に, 図 10 に対応して, 前輪が路面と突起より受ける 外力のシミュレーション結果を図 11 に示す. この図からも, 車輪に作用する衝撃外力がほぼ同じでありながら, 
撃心対応点 $\mathrm{Q}_{2}$ が回転ヒンジ中心にある場合の衝撃加速度抑制効果が確認される. また, この外力の応答結果より, 衝突後に生じる車台の負方向の大きな加速度は, 前輪と路面との 2 回目の衝突により生じていると推察される.

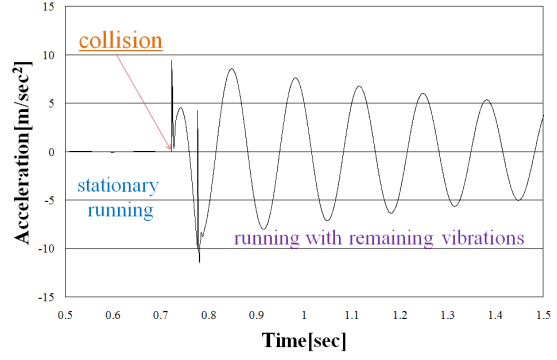

a) Hinge center $Q_{1}$

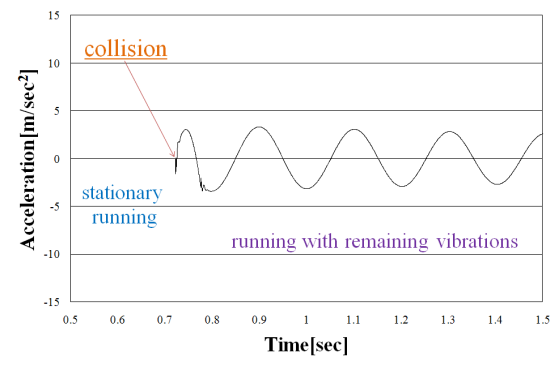

b) Hinge center $Q_{2}$

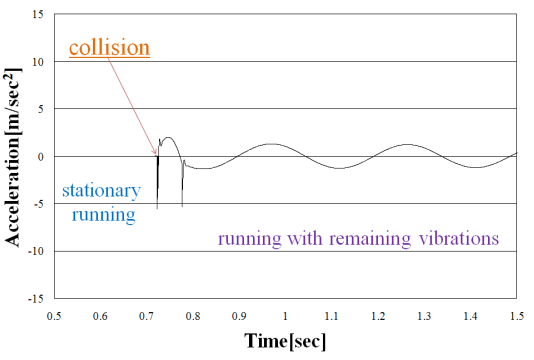

c) Hinge center $Q_{3}$

Fig.9 Simulation results of wagon with a coiled spring

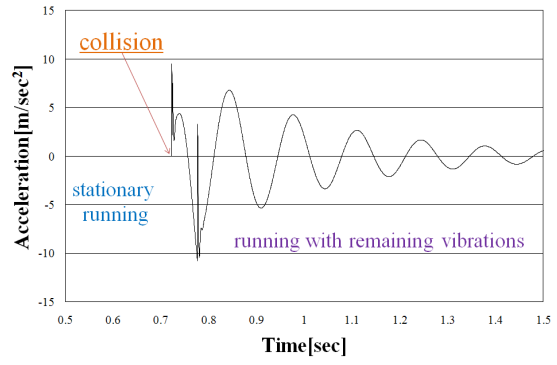

a) Hinge center $Q_{1}$

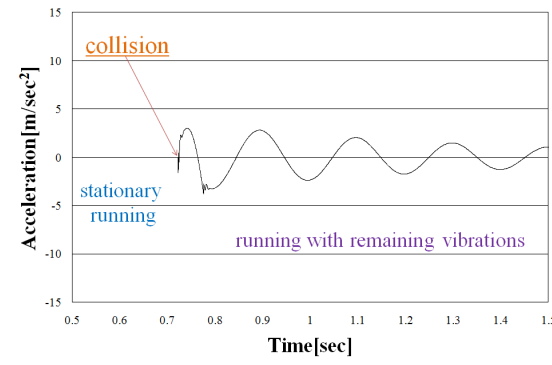

b) Hinge center $Q_{2}$

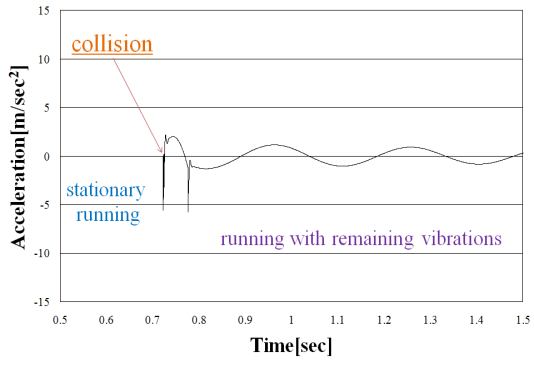

c) Hinge center $Q_{3}$

Fig.10 Simulation results of wagon with a urethane damper

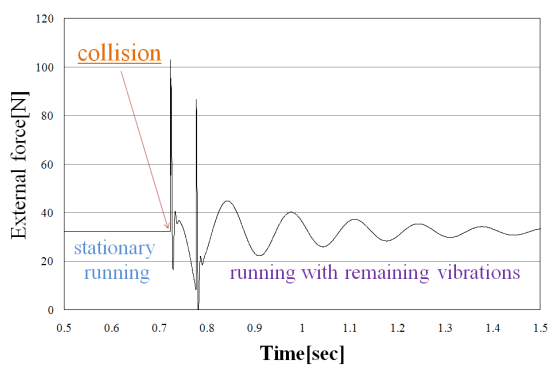

a) Hinge center $Q_{1}$

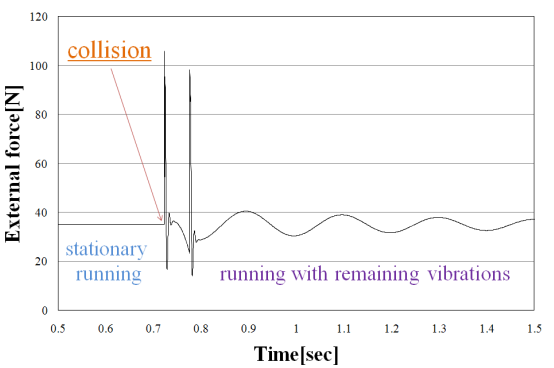

b) Hinge center $Q_{2}$

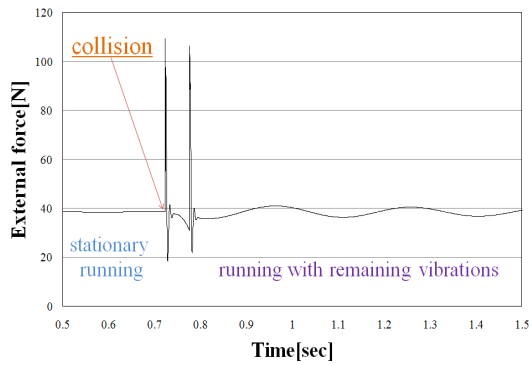

c) Hinge center $Q_{3}$

Fig.11 Simulation results of external force corresponding to Fig.10

\section{5. お り に}

本論文では，撃心を利用したキャスター単体の設計を提案し，その効果を詳細に検討するためにキャスター付 き台車の運動モデルを作成した，さらに，回転ヒンジの取り付け位置が変更可能なキャスターを製作して，キャ スター付き台車の走行実験を行い，撃心を利用したキャスターが車台の衝撃緩和に有効であることを示した。得 られた主な内容を以下にまとめる.

(1) 車台の衝撃緩和のために，キャスターを構成する摇動アームに撃心の考え方を適用することを提案した.

(2) 路面突起物が台車に与える衝撃把握のために, キャスター付き台車の力学モデルを導出した.

（3）ヒンジ位置が変更可能なキャスターを使って，台車の突起乗り上げ走行実験を行い，車台の衝撃加速度応 答を計測した.

（4）ヒンジ位置を摇動アームの撃心とする場合，車台の衝撃加速度が減じられることを確認した．特に，突起 衝突後に路面に再衝突する場合の衝撃緩和効果が大きい. 
(5) 実験結果とシミュレーション結果は同様の傾向を示し，台車のモデル化が妥当であることを確認した.

最後に，今後も継続的に取り組むべき研究開発課題について述べる.

摇動リンク単体の撃心に着目したキャスターの設計は台車の衝撃緩和に効果が見られたが，台車の重量や重心 を考慮した場合のより優れた摇動リンクの設計が望まれる. また, 進行方向からの衝撃分力の影響も勘案したき め細かい設計も重要である. さらに, 将来的には台車の手押しを行う場合の力の入れ具合も考慮した設計が必要 になると思われる.

シミュレータに関しては定性的に実験とのよい一致が見られたが，路面突起に衝突して最初に生じる第 1 衝撃 加速度の後に現れる正方向の加速度に実験との差異が見られた．車軸径と車輪穴径の誤差が，実験とシミュレー ション条件で異なることが要因であると予想されるが，詳細な比較検討は今後の課題である. さらに, 路面を等 速移動させて台車の移動を模擬するのでなく, 進行方向からの外力も考慮した車台自体を動かせるシミュレータ に改良する必要性も考えられる. 加えて, 車輪の回転慣性効果を台車モデルに反映させることも重要である.

\section{文献}

(1) シシクアドクライス，“衝撃を和らげるキャスター”，特願 2004-558428.

(2) ユーエイキャスター, “油圧式ダンパー及びそれを用いた油圧式ダンパーキャスター”, 特願 2007-25925.

(3) ユーエイキャスター, “複合ダンパー”, 特願 2007-135614.

(4) コマツユーティリティ, “作業車両”, 特願 2007-255227.

(5) デンソー, “搬送台車”, 特願 2007-314153.

（6）末岡淳男，綾部隆，“機械力学”，森北出版 (1997), pp.78-79.

(7) 喜多秀次, 宮武義郎, 徳岡善助, 山崎和夫, 幡野茂明, “力学”, 学術図書 (1975), pp.234-235 .

(8) Wilson Sporting Goods Company，“壁厚の変化する内挿材を有するボールバット”特願 2005-7458.

(9) 横浜ゴム, “ゴルフクラブヘッド”, 特願 2004-25176.

(10) Acushnet Company, “多材ゴルフクラブヘッド”, 特願 2007-212484.

(11) 相山康道, “受動関節を有するロボットマニピュレータ”, 日本設計工学会誌, Vol.44, No.4 (2009), pp.189-195.

(12) 荒井裕彦, 谷江和雄, 城間直司, “非駆動関節を有寸る水平 3 軸マニピュレータの非ホロノミック拘束下における フィードバック制御," 日本ロボット学会誌, Vol.15, No.6 (1997), pp.943-952.

（13）城間直司，荒井裕彦，谷江和雄，“複数の非駆動関節を有する連結平面剛体の非ホロノミック運動計画”，日本機械 学会論文集 (C 編), Vol.66, No.642 (2000), pp. 553-560.

(14) 須田敦, 山本昌彦, 五百井清, “ばね埋没型ウレタンダンパの設計開発”, 日本設計工学会平成 22 年度秋季大会研 究発表講演会講演論文集, (2010), pp.37-40.

(15) 杉原知道, “零衝撃機構の開発”, 日本機械学会ロボティクス・メカトロニクス講演会予稿集 CD-ROM (2008), 2A1-102.

(16) Moriya, K., Kawabuchi, T., Ioi, K., Suda, A., Yamamoto, M., "Dynamic Analysis of Wagon caster with Shock absorber", Proceeding of SICE Annual Conference, (2010), pp.1250-1254. 